\title{
Laboratory and industrial synthesis of remifentanil
}

\author{
František Mathia, Štefan Marchalín, Daniel Végh, \\ Mária Bobošíková and Michaela Halinkovičová \\ Institute of Organic Chemistry, Catalysis and Petrochemistry, Faculty of Chemical and Food Technology, \\ Slovak University of Technology, Radlinského 9, SK-812 37 Bratislava, Slovak Republic \\ mathia.f@gmail.com
}

\begin{abstract}
The submitted review aims at critical evaluation of known synthetic procedures utilized both for laboratory and industrial production of the synthetic analgesic - remifentanil as to their simplicity, published yield and atom economy.
\end{abstract}

Keywords: remifentanil, synthesis, analgesics

\section{Introduction}

Remifentanil - systematic name methyl ester of the 3-[4-methoxycarbonyl-4-[(1-oxopropyl)phenylamino]-1-piperidine]propanoic acid (1) - is a synthetic analgesic, marketed, as a hydrochloride, by GlaxoSmithKline, Ganval, Belgium under the trade name of Ultiva ${ }^{\circledR}$. It belongs to the fast onset, ultra short to long acting analgesics, used as co-analgesics for safe management of general anesthesia during surgery, for management of postsurgery situations or for treatment of hyperalgesia (increased sensitivity to pain) (Guntz et al., 2005). In the human blood remifentanil is metabolized by non-specific blood esterases to essentially inactive metabolite of carboxylic acid. (Feldman et al., 1991). Metabolic half-time in human blood reaches from 10 to 20 minutes (Amin et al., 1995). Remifentanil, its preparation and properties were first published in 1990 (EP0383579, Glaxo Wellcome Inc. (Fig. 1)

\section{Synthetic approaches to remifentanil}

The primary reference (EP0383579) describes the preparation of remifentanil by derivatization of the starting piperidone. The synthetic pathway, designed from the outset for the preparation of remifentanil starts from the commercially available N-benzylpiperidin-4-one (2) (WO0140184A2). (Scheme 1)

In its first step Strecker synthesis is used to introduce N-phenylamine and nitrile group, both in the position 4 of the heterocyclic skeleton. Acylated $\mathrm{N}$-phenylamine group can also be found in the structure of target remifentanil. The nitrile group in the molecule (3) conveniently serves as a precursor to the carboxylic group. In its paper Kiricojevič observed a significant acceleration of the Strecker reaction by the use of mixed dichloromethane/acetic acid solvent, explaining the effect by the better solubility of the in situ generated hydrogen cyanide as compared to pure acetic acid (Kiricojević et al., 2002). The hydrolysis of nitrile (3) proceeds in two steps involving an amide (4), mainly to avoid the formation of nonreactive and insoluble sulfate (4). The liberation of free base is followed by acid $(\mathrm{HCl})$ hydrolysis of the amide (4) (Scheme 1). Amide (4) can also be hydrolyzed in basic conditions by the system $\mathrm{KOH} /$ propane-1,2-diol/18-crown-6. It would be tempting to "improve" the two-step transformation of nitrile (3) to acid (5) by a one-pot reaction<smiles>CCC(=O)N(c1ccccc1)C1(C(=O)OC)CCN(CCc2ccccc2)CC1</smiles>

Carfentanil<smiles>CCC(=O)N(c1ccccc1)C1(COC)CCN(CCc2cccs2)CC1</smiles>

Sufentanil<smiles>CCC(=O)N(c1ccccc1)C1(COC)CCN(CCn2nnn(CC)c2=O)CC1</smiles><smiles>CCC(=O)N(c1ccccc1)C1(C(=O)OC)CCN(CCC(=O)OC)CC1</smiles>

Alfentanil
Remifentanil (1)

Fig. 1. Remifentanil and its analogs. 
<smiles>N#CC1(Nc2ccccc2)CCN(Cc2ccccc2)CC1C(=O)O</smiles><smiles>CCC(=O)N(c1ccccc1)C1(C(=O)OC)CCNCC1</smiles><smiles>C=CC(=O)OCCOC(=O)CCN1CCC(C(=O)OC)(N(C(=O)CC)c2ccccc2)CC1</smiles>

Scheme 1.<smiles>NC(=O)C1(Nc2ccccc2)CCN(Cc2ccccc2)CC1</smiles>

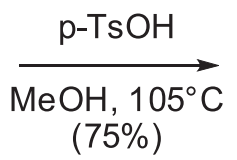<smiles>COC(=O)C1(Nc2ccccc2)CCN(Cc2ccccc2)CC1</smiles>

Scheme 2.

in acidic conditions. Moreover, by judicious choice of solvent one could arrive directly at the methyl ester of the acid, i.e. the intermediate (6). In spite of numerous attempts (Kiricojević et al., 2002) the direct, one step transformation of intermediate (3) to carboxylic acid (5) could not be achieved in acceptable yields. Attempts at basic hydrolysis of the nitrile functionality led to the products of markedly faster retro-Strecker reaction (analogy of the Bruylant decyanization of amines (Kudzma, et al., 1988)) (Kiricojević et al., 2002; Feldman et al., 1990; Marco et al., 1999)).

Nevertheless Taber suggested a slight modification of the synthetic sequence and its shortening by one step. In its paper he describes a direct hydrolysis of amide (4) to the methyl ester (6) in good (75\%) yield. Although it would clearly simplify the sequence, no known industrial production of remifentranil has adopted this variation of hydrolysis (Taber et al., 1992). (Scheme 2)

Because of costly safety considerations involving work with toxic hydrogen cyanide, created in situ during the Strecker synthesis, an alternative route to 4,4-disubstituted piperidine has been developed, starting from the piperidone (9). (Scheme 3)

In its first step it involves in place of nitrile the intermediate formation of ethyl ester of 4-phenylamino4-phenylcarbamoylpiperidinecarboxylic acid (11), known from several syntheses of related derivatives. (WO0140184A2)

Another seemingly simple synthetic step, but one which made quite a few synthetic teams sweat, was the formation of the important intermediate ester (6) within the original synthetic plan. (Scheme 1) Apart from preparation of the ester from amide (4), which is not used commercially (Scheme 2), preparation of 


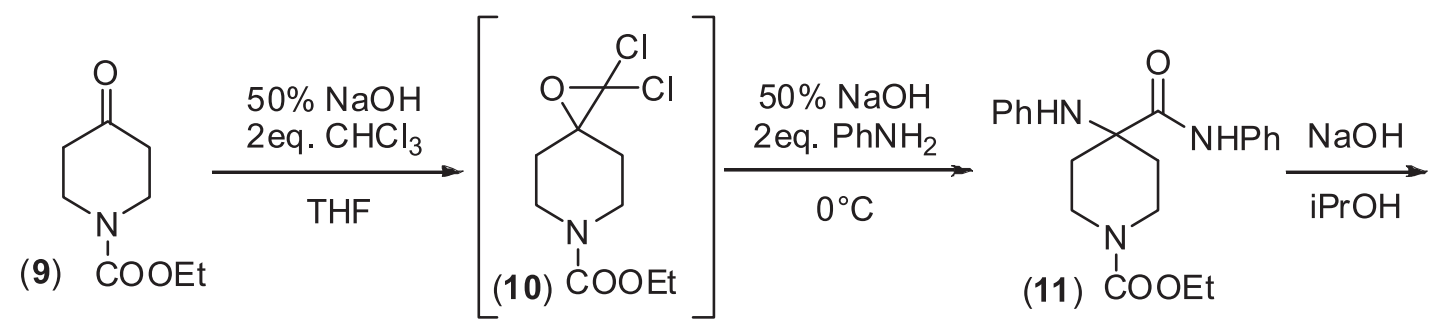<smiles>NC1(C(=O)NC2CCNCC2)CCNCC1</smiles><smiles>COC(=O)[C@H](OC)C(OC)OC</smiles><smiles>CCOC(=O)CC1(NC(=O)CC)CCN(CCC(OC)OC)CC1</smiles>

Scheme 3.<smiles>O=C(O)C1(Nc2ccccc2)CCN(Cc2ccccc2)CC1</smiles>

\section{$\underset{\text { reflux, 10d }}{\stackrel{\mathrm{EtOH} / \text { toluene }}{\longrightarrow}}$}

Dean-Stark apparatus

$(80 \%)$

Scheme 4.<smiles>O=C(O[Na])C1(Nc2ccccc2)CCN(Cc2ccccc2)CC1</smiles>

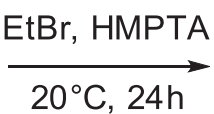

$\underset{\substack{90^{\circ} \mathrm{C}, 5 \min \\(65 \%)}}{\stackrel{\text { Mel, DMF }}{\longrightarrow}}$<smiles>CCOC(=O)C1(Nc2ccccc2)CCN(Cc2ccccc2)CC1</smiles><smiles>COC(=O)C1(Nc2ccccc2)CCN(Cc2ccccc2)CC1</smiles>

Scheme 5 .

ester requires the acid (5), or its salt. Several papers describe especially the acid (5) as a hard to isolate and purify compound, which is preferably converted to its alkaline salt ( $\mathrm{Na}$, $\mathrm{K}$, etc.). Esterification in acidic conditions represents an equilibrium reaction which, in order to achieve acceptable yields, requires long reaction time, high temperature and possibly further modification of reaction conditions. (Colapret et al., 1989) (Scheme 4)

The reaction of the sodium salt of acid (15) with an alkyl halide proceeds in good yield in hexamethylphosphortriamide - HMPTA (Scheme 5) (Van Parys et al., 1981); the yield plummets to an average one (58\%), when dimethylformamide is used (Feld- 
<smiles>O=C(O)C1(Nc2ccccc2)CCN(Cc2ccccc2)CC1</smiles>

4eq $\mathrm{SOCl}_{2}$, cat. DMF

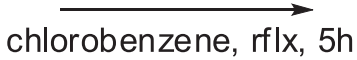
then $\mathrm{MeOH}$, r.t., $1 \mathrm{~h}$

$(41 \%)$<smiles>COC(=O)C1(Nc2ccccc2)CCN(Cc2ccccc2)CC1</smiles>

Scheme 6.<smiles>N#CC1(Nc2ccccc2)CCN(Cc2ccccc2)CC1</smiles><smiles>N#CC1(N(C(=O)NS(=O)(=O)Cl)c2ccccc2)CCN(Cc2ccccc2)CC1</smiles><smiles>O=C(O[Na])C1(Nc2ccccc2)CCN(Cc2ccccc2)CC1</smiles>

Scheme 7.
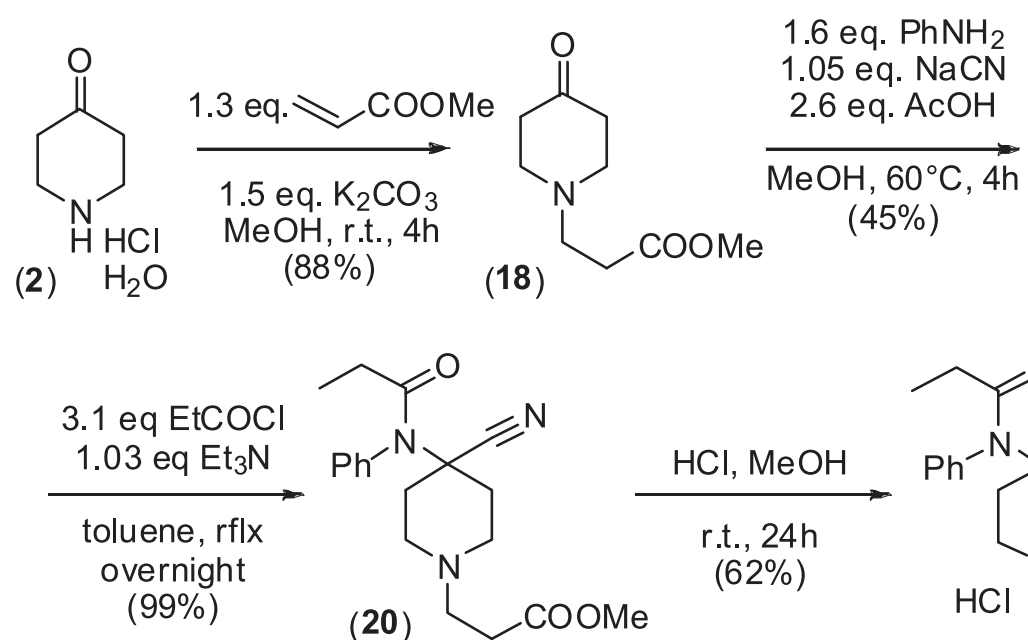<smiles>COC(=O)CCN1CCC(C#N)(Nc2ccccc2)CC1</smiles>

(18)

(19)<smiles>CCC(=O)N(c1ccccc1)C1(C#N)CCN(CCC(=O)OC)CC1</smiles><smiles>CCC(=O)N(c1ccccc1)C1(C(C)=O)CCN(CCC(C)=O)CC1</smiles>

Scheme 8.

man et al., 1990). Higher proportion of alkylating agent leads to partial alkylation at nitrogen atom, or affords a mixture of products. (Scheme 5)

Activation of carboxylic acid by its conversion to chloride proved difficult, probably for steric reasons. This is why Kiricojevič, trying this approach to ester (6) only got low yield (41\%) in spite of severe reaction conditions (Scheme 6) (Kiricojević et al., 2002).

Feldman too described an alternative method of transformation of the nitrile (3) to the sodium carboxylate (5), based on utilization of chlorosulfonyl isocyanate for the preparation of spirohydantoin (17) as an intermediate (Scheme 7) (Feldman et al., 1990). However, derivative (17) was obtained only in average yield due to partial conversion of the carbamoylsulfonyl chloride (16) to nitrile (3), accompanying its further decomposition to the product of retro-Strecker reaction - the piperidone (2). The principal drawback of this approach is the high stability of the spirohydantoin (17), making the preparation of sodium salt (15) energetically demanding.

Scheme 1 through 3 depicts preparations of remifentanil requiring protection of the piperidine nitrogen. In 2006 an alternative procedure has been patented, one starting from the piperidine-4-one (2) (or its hydrochloride) (Scheme 8) (EP1867635A1), and affording the target remifentanil (1) in 4 steps and $24 \%$ overall yield. In this case authors achieved in the final step a direct conversion of nitrile to methyl ester in good yield (62\%).

Literature search (Reaxys, Scifinder) disclosed a solventless propionylation of the anilide nitrogen in 
<smiles>COC(=O)C1(Nc2ccccc2)CCN(Cc2ccccc2)CC1</smiles><smiles>CCOC(=O)OCCOC(=O)C1(N(C(=O)CC)c2ccccc2)CCN(Cc2ccccc2)CC1</smiles><smiles>COCC1(Nc2ccccc2)CCN(Cc2ccccc2)CC1</smiles><smiles>CCC(=O)N(c1ccccc1)C1(COC)CCN(Cc2ccccc2)CC1</smiles>

Scheme 9.<smiles>O=C(O)C1(Nc2ccccc2)CCN(Cc2ccccc2)CC1</smiles><smiles>CCC(=O)OC1(CC)OC(=O)C2(CCN(Cc3ccccc3)CC2)N1c1ccccc1</smiles><smiles>CCC(=O)N(c1ccccc1)C1(C(=O)OC)CCN(Cc2ccccc2)CC1</smiles>

Scheme 10.

substrate (6) by exclusive use of a high excess of propionic anhydride at $170{ }^{\circ} \mathrm{C}$. Neverthelss, the yields of this trasformation are either rather low ((23\%), Henriksen et al., 2005), ((34 \%), US201099880A1) or not given at all (US3998834 A1, US4179569A1). A comparison with analogous propionylations of substrates leading to norsufentanyl or closely related derivatives leads one to the conclusion that lower reactivity of the anilide nitrogen in the substrate (6) is probably due to the proximity of the sterically demanding methoxycarbonyl group. (Srimurugan et al., 2009) (Scheme 9)

According to Kiricojevič the ester (6) failed to react with propionyl chloride in DCM even after several days of reflux. In chlorobenzene at temperature elevated to $100-120{ }^{\circ} \mathrm{C}$ a significant part of the substrate decomposed, as was the case during reflux in neat propionic anhydride. Conversely, at low temperature the reactivity of propionic anhydride does not suffice for successful propionylation. An addition of bases on the other hand, either pyridine or DMAP led to complex reaction mixtures. In the end acceptable yields of the acylated product ( 7 ) were obtained by use of propionyl chloride (3 eq.) in dichloroethane $\left(80{ }^{\circ} \mathrm{C}, 4-5 \mathrm{~h}\right)$, to which triethylamine was gradually added (1 eq.). The product was isolated in the form of monooxalate salt in the yields of 70-80\%. (Kiricojević et al., 2002)

In 1999 Coleman solved the problem of low nucleophilicity of the secondary amine nitrogen in an elegant way. He let react the amino acid (5) with excess propionic anhydride in the presence of triethylamine, whereby the in situ generated spirocyclic intermediate (23) underwent a ring opening by methanol to the intermediate (7) in very good yield. (Scheme 10) (Coleman et al., 1999)

The debenzylation of ester ( 7 ) was carried out in the conditions of catalytic hydrogenation with metals - $\mathrm{Pd}$ and/or $\mathrm{Pd}(\mathrm{OH})_{2}$ (Scheme 1, Table 1). Another potentially applicable debenzylation uses 1-chloroethyl chloroformate, i.e. transformation of compounds (24) to (25), as has been repeatedly 
<smiles>[Z6]c1ccccc1CN1CCC(c2ccccc2)(N(C(=O)CC)c2ccccc2F)CC1</smiles>

1.) $1.17 \mathrm{eq}$<smiles>CC(Cl)OC(=O)Cl</smiles>

DCE, rflx, $2 \mathrm{~h}$

2.) $\mathrm{MeOH}, \mathrm{rflx}, 4 \mathrm{~h},(80 \%)$<smiles>CCC(=O)N(c1ccccc1F)C1(c2ccccc2)CCNCC1</smiles>

Scheme 11.

Tab. 1. Debenzylation of substrate (7)

\begin{tabular}{llcccccc}
\hline Catalytic system & Solvent & $\begin{array}{c}\mathrm{p}\left(\mathrm{H}_{2}\right) \\
{[\mathrm{atm}]}\end{array}$ & $\begin{array}{c}\mathrm{t} \\
{[\mathrm{h}]}\end{array}$ & $\begin{array}{c}\mathrm{T} \\
{\left[{ }^{\circ} \mathrm{C}\right]}\end{array}$ & $\begin{array}{c}\mathrm{Y} \\
{[\%]}\end{array}$ & Ref. \\
\hline 1 & $15 \%$ wt. $\mathrm{Pd} / \mathrm{C}(10 \%)$ & $\mathrm{MeOH}$ & $\mathrm{atm}$ & - & r.t. & 85 & US3998834A1 \\
\hline 2 & $20 \%$ wt. $\mathrm{Pd} / \mathrm{C}(5 \%)$ & $\begin{array}{c}\mathrm{MeOH} / \mathrm{EtCOOMe} / \mathrm{AcOH} \\
60: 2: 1\end{array}$ & $\mathrm{~atm}$ & $\begin{array}{c}\text { over- } \\
\text { night }\end{array}$ & 50 & $50^{\mathrm{a}}$ & US201099880A1 \\
\hline 3 & $30 \%$ wt. $\mathrm{Pd} / \mathrm{C}(10 \%)$ & $\mathrm{EtOH}$ & atm & 24 & r.t. & 52 & Henriksen et al., 2005 \\
\hline $\begin{array}{l}20 \% \text { wt. } \mathrm{Pd} / \mathrm{C}(10 \%) / \\
\mathrm{Pd}(\mathrm{OH})_{2} / \mathrm{C}(10 \%) \\
1: 1\end{array}$ & $\mathrm{MeOH}$ & 4 & 12 & r.t. & 92 & Srimurugan et al., 2009 \\
\hline 5 & $\begin{array}{l}10 \% \text { wt. } \mathrm{Pd} / \mathrm{C}(10 \%) \\
5 \text { ekv. } \mathrm{HCl}\end{array}$ & $\begin{array}{c}\mathrm{AcOH} / \mathrm{H}_{2} \mathrm{O} \\
2: 3\end{array}$ & $3-4$ & $3-4$ & 20 & 95 & Kiricojević et al., 2002 \\
\hline
\end{tabular}

a) GC conversion

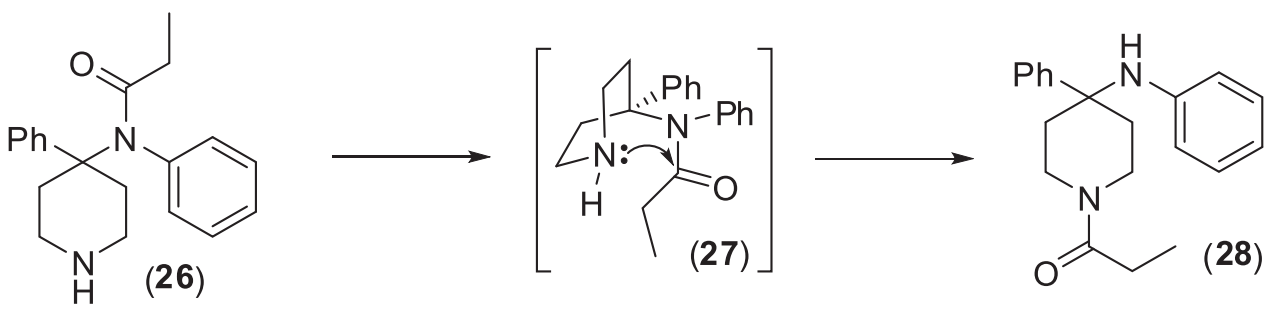

Scheme 12.

demonstrated on analogous substrates. (Scheme 11) (Kudzma et al., 1988)

It should not be forgotten though that debenzylation involves an intramolecular acyl migration, specifically that of propionyl from aniline nitrogen (26) via (27) to piperidine nitrogen (28). (Scheme 12) (Kudzma et al, 1988, Colapret et al. 1989). This undesirable process can largely be eliminated by speedy workup of the product of debenzylation on the one hand, and by selection of effective and fast debenzylation conditions on the other.

There are several ways to carry out final alkylation of the piperidine ring, the most common one being the Michael reaction at the double bond of methyl acrylate, or nucleophilic substitution by various alkyl halides or alcohols. This was how the series of $\mathrm{N}$-substituted derivatives of piperidine (29) and (30) were prepared. (Scheme 13) (Feldman et al., 1990)
The introduction of methoxycarbonyl ethyl group into the remifentanil molecule is done exclusively by the Michael addition. Numerous experiments were required to select reaction conditions (Scheme 14) leading to formation of the final product (1) in high yield and high purity (over $99 \%$ ), followed by the removal of remifentanil (1) from reaction medium by simple filtration. (US2011144346A1)

Another synthetic strategy leading to remifentanil is based on the Ugi reaction. Malaquin and coworkers applied Ugi reaction to the preparation of remifentanil in 2010. (Scheme 15)(Malaquin et al., 2010). Its big advantage lies in the effectiveness of the synthetic sequence (3 steps starting from commercially available compounds), one equivalent Ugi procedure (no excess required) and good yield. To be specific, mixing of equimolar amounts of propionic acid (31), aniline (32), piperidone (18) and cyclohexenylisonitrile (33) gives rise to the interme- 

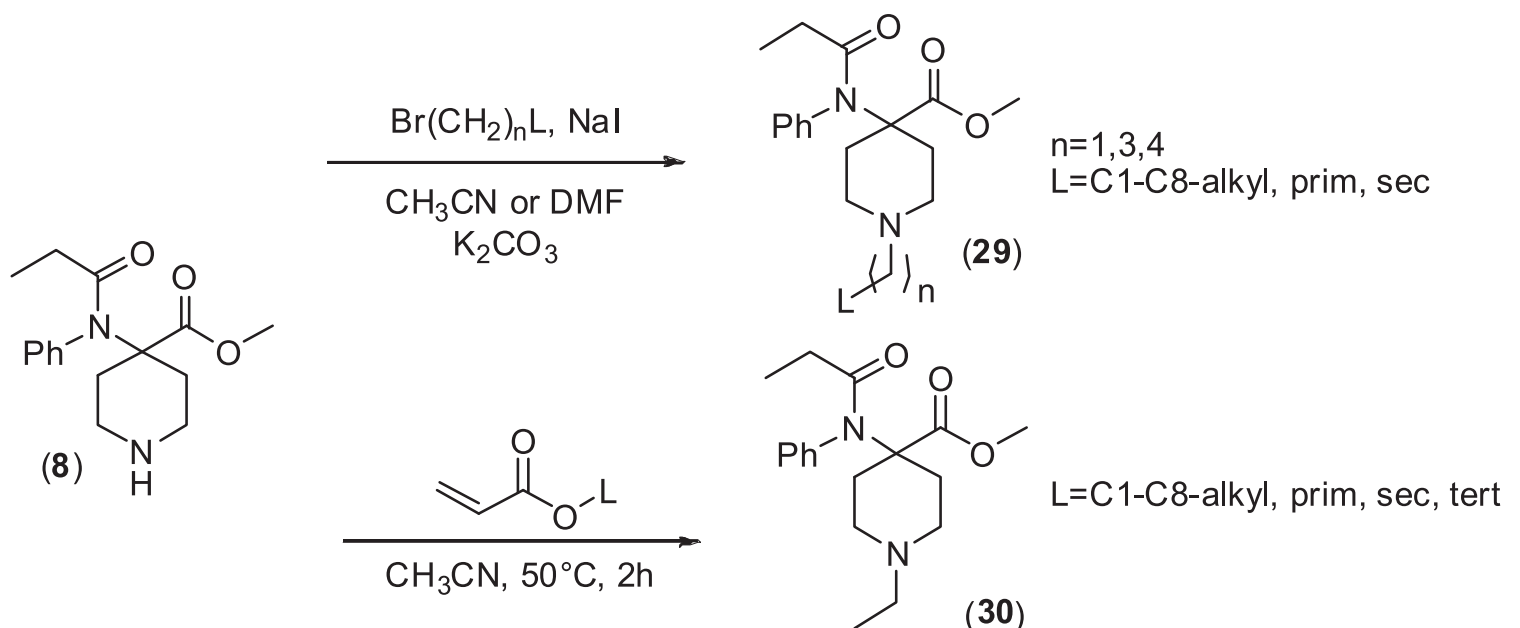

Scheme 13.

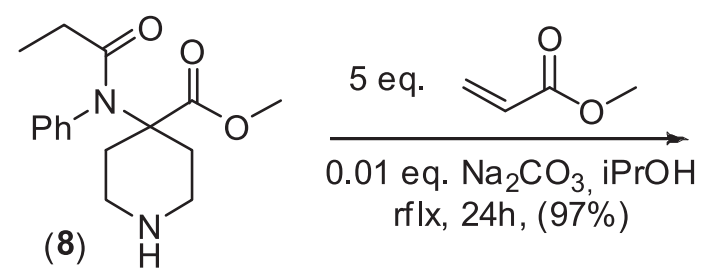<smiles>CCC(=O)N(c1ccccc1)C1(C(=O)OC)CCN(CCC(=O)OC)CC1</smiles>

Scheme 14.

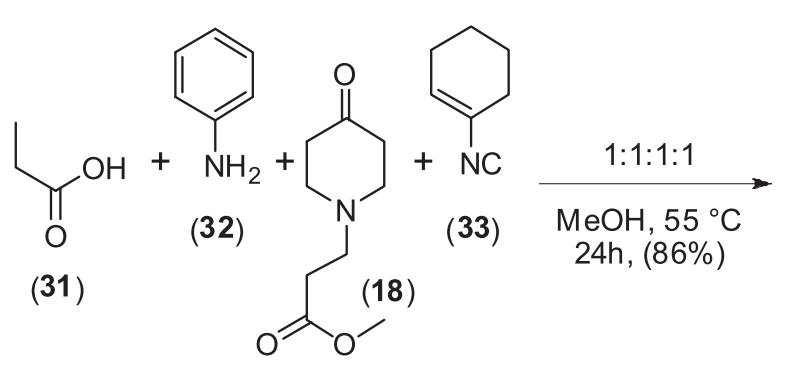<smiles>CCC(=O)N(c1ccccc1)C1(C(=O)NC2=CCCCC2)CCN(CCC(=O)OC)CC1</smiles><smiles>CCC(=O)N(c1ccccc1)C1(C(=O)OC)CCN(CCC(=O)OC)CC1</smiles>

Scheme 15.

diate (34) which, after simple transformation amide to methyl ester afforded the final remifentanil (1) in $75 \%$ overall yield. From the viewpoint of industrial manufacturing the drawback of the published method is the use of chromatographic methods for product purification.

\section{Acknowledgement}

This contribution is the result of the project: Research Center for Industrial Synthesis of Drugs, ITMS 26240220061, supported by the Research E Development Operational Programme funded by the ERDF.

\section{References}

Amin HM, Sopchak AM, Esposito BF, Henson LG, Batenhorst RL, Fox AW, Camporesi EM (1995) J. Pharmacol. Exp. Ther. 274: 34-39.

Colapret JA, Diamantidis G, Spencer HK, Spaulding TC, Rudo, FG (1989) J. Med. Chem. 32: 968-974.

Coleman MJ, Googyear MD, Latham DWS, Whitehead AJ (1999) Synlett: 1923-1924.

EP0383579.

EP1867635A1.

Feldman PL, Brackeen MF (1990) J. Org. Chem. 55: 4207-4209. 
Feldman PL, James MK, Brackeen, MF, Bilotta JM, Schuster SV, Lahey AP, Lutz MW, Johnson MR, Leighton HJ (1991) J. Med. Chem. 34: 2202-2208.

Guntz E, Dumont H, Roussel C, Gall D, Dufrasne F, Cuvelier L, Blum D, Schiffmann SN, Sosnowski M (2005) Anesthesiology 102: 1235-1241.

Henriksen G, Platzer S, Marton J, Hauser A, Berthele A, Schwaiger M, Marinelli L, Lavecchia A, Novellino E, Wester HJ (2005) J. Med. Chem. 48: 7720-7732.

Kiricojević VD, Ivanović MD, Mićović IV, Djordjević JB, Roglić GM, Došen-Micović LJ (2002) J. Serb. Chem. Soc. 67: 793-802.

Kudzma LV, Spencer HK, Severnak SA (1988) Tetrahedron Lett. 29: 6827-6830.

Malaquin S, Jida M, Gesquire JC, Deprez-Poulain R, Deprez B, Laconde G (2010) Tetrahedron Lett. 51: 2983-2985.
Marco JL, Ingate ST, Chinchon PM (1999) Tetrahedron 55: 7625-7644.

Srimurugan S, Murugan K, Chen C (2009) Chem. Pharm. Bull. 57: 1421-1424.

Taber DF, Rahimizadeh M (1992) J. Org. Chem. 57: 4037-4038.

US201099880A1.

US2011144346A1.

US3998834A1.

US4179569A1.

Van Parys M, Vanderwalle, M (1981) Bull. Soc. Chim. Belg. 90: 749-755.

WO0140184A2. 